Esta obra está sob o direito de Licença Creative Commons Atribuição 4.0 Internacional.

\title{
A EXPERIÊNCIA DO CATOLICISMO REVOLUCIONÁRIO NO BRASIL.
}

\author{
Célia Nonata da Silva
}

\begin{abstract}
RESUMO
Este artigo é uma análise sobre a influência da Igreja Católica nos movimentos sociais e lideranças no campo no Brasil. O discurso religioso constituiu a base para os conflitos de terras e da formação das lideranças católicas no campo, enquanto matriz ideológica desses sujeitos participantes na estratégia de acesso à terra pelos trabalhadores rurais. Este repertório discursivo dos sujeitos sociais traduz uma consciência histórica processual desde o século XIX com o perfil de uma Igreja social pelos movimentos da Ação Católica até as Conferências de Medellín e Puebla na América Latina, que (re)posicionaram a postura da Igreja progressista sob um enfoque teórico-metodológico calcado na Doutrina Social e na Teologia da Libertação. Atualmente, a atuação desta Igreja progressista, através do CIMI, aproxima seu discurso aos modelos de uma concepção ambientalista e globalista, enaltecendo valores éticos concernentes ao paradigma da nova esquerda.
\end{abstract}

Palavras-chave: revolução, Igreja, socialismo, progressivismo, terra.

\footnotetext{
${ }^{3}$ Possui graduação em História pela Universidade Federal de Minas Gerais (1995), mestrado em História pela Universidade Federal de Minas Gerais (1998) e doutorado em História das Culturas Políticas pela Universidade Federal de Minas Gerais (2004). Atualmente é professora Associada II do curso de História da Universidade Federal de Alagoas, onde também coordenou o curso de Pós-Graduação LATU SENSU "História Social do Poder", a graduação em Bacharelado em História e atualmente coordena a Pós-Graduação Ead: "História e ensino de História'. É membro do conselho editorial da Revista Sertões (UERN), da Revista Prima Facie do curso de Direito da Universidade Federal da Paraíba e da Revista Crítica Histórica do Curso de História da UFAL. Coordena o GRUPO DE PESQUISA: HISTÓRIA SOCIAL DO CRIME. Também é autora dos livros: Territórios de Mando: banditismo em Minas Gerais, século XVIII. Crisálida, 2007; Entre Lobos: femicídio e violência de gênero em Alagoas, 2015. Possui vários artigos publicados na temática da violência e criminalidade em Alagoas.
} 


\section{INTRODUÇÃ̃O}

Saber o que o passado nos diz através de homens que o vivenciaram é um dado muito importante. Aleksandr Soljenítsin (1918-2008), intelectual e poeta soviético, mostrou ao mundo as atrocidades do regime stalinista através de seus livros, tais como: Arquipélago Gulag, agosto 1914, O Primeiro Círculo, dentre outros. Ion Pacepa (2021) ao desertar da KGB coloca para o mundo as atrocidades e ardis do regime soviético e seus tentáculos até dentro da Igreja Católica. Várias situações como a 'Operação Dragão' com o objetivo de dominar a América Latina por métodos de desinformação, reprogramação cultural, meios de comunicação como o cinema, imprensa e outros. Ainda que poucos relutem em duvidar de tais acontecimentos totalitários, bem como a extensão perversa desse poder, a não repetição dos mesmos faz com que a humanidade tenha precaução. Sabemos que a mudança de narrativas não invalida a pretensão dos regimes totalitários socialistas tentarem o presente, serpenteando o futuro. Ainda que seja surpreendente que narrativas ainda contumazes sejam pregadas como algo valoroso num campo de batalha já derrotado. Nesta seara, a Igreja Católica, através da Teologia da Libertação, tem proposto uma mudança de perspectiva inovadora para a atuação e práxis revolucionária socialista. Esta Nova Teologia, fruto da Revolução Francesa e sua tentativa igualitária desde o século XVIII começará a mudar o rumo de uma antiga instituição religiosa para uma ilha perdida nos mares tumultuosos da ideologia comunista. Em que pese a crítica veemente de Aleksandr Soljenítsin quanto ao regime socialista e comunista como um todo, a Nova Teologia libertária da Igreja
Católica vem promovendo uma tentativa de revolução usando a Igreja como instrumento político para a consolidação da um poder Socialista Universal.

Um poder que se identifica com movimentos totalitários, cuja tradição cristã deveria ser avessa totalmente. Mesmo que alguns de seus adeptos hoje condenem essa adesão ideológica da Igreja a tais sistemas totalitários, não obstante comungam de ideais progressistas não tão ilesos de críticas. Mas, o que realmente pode-se entender como equivocado na Teologia da Libertação? Seu método? Sua proposta filosófica? Primeiramente devemos esclarecer determinados pontos importantes. De forma alguma deve-se confundir a inspiração da Teologia da Libertação como um movimento inspirado no Evangelho. A nova Teologia rompe definitivamente com a tradição da Igreja Católica curvando-se ao idílico e ilusório caminho da revolução dos Iguais. Vamos ver: uma coisa é Cristo pregar a compaixão pelos pobres, a caridade com os menos favorecidos e enaltecer o desprendimento material. Outra situação é Marx utilizar os pobres como instrumento de mudança política, de destruição do capitalismo para o favorecimento de num projeto socialistacomunista com sérios problemas de concretização social. Os defensores da Teologia da Libertação foram adeptos das alternativas revolucionárias, de mudanças sociais pelo uso da violência e do enfrentamento político, levando aos púlpitos não apenas as denuncias de explorações sociais, mas usando da violência como marca expressa dessa fé.

Mormente, em nome dos pobres, a Teologia da Libertação propõe um lugar melhor para se viver. Entretanto, o mundo físico, terrestre poderia ser mudando sem o alcance da mudança interior do ser 
humano? Isso não é importante para a Nova Teologia. Não existe nenhuma espiritualidade na proposta teologal. Como herdeira do humanismo, essa teologia reafirma a pessoa humana não apenas como o centro do mundo político e social, mas aceita-o como plenamente independente de uma consciência católica de mundo, que deveria resguarda-lo. Nas palavras de um jesuíta: "Assim, não deveria surpreender o fato de hoje existirem cristãos marxistas, cristãos maoístas, cristãos trotskistas, cristãos socialistas, cristãos castristas. Por vezes, parece que o cristianismo é capaz de adotar qualquer coisa que aparece na cena política" (SCHALL, 2020, p. 61).

De fato, a Igreja Católica deve sempre olhar para a realidade histórica e seu tempo dentro das verdades teologais da Tradição e, com isso, propor a vivencia possível da bem-aventurança e do bem comum. Assim contribuiu a Escola de Salamanca para perceber e adequar as novas realidades históricas dentro da premissa da Tradição. Ao fazer isso, Francisco de Vitória, Bernardino de Siena, De Molina, Bartholomé de Las Casas e tantos outros revolucionaram definitivamente seu tempo e o futuro promovendo a equanimidade dos novos fatos. Propuseram a pensar sobre a propriedade privada e a propriedade em comum, sobre a liberdade do indivíduo contra qualquer forma de escravização, sobre os preços e produção, sobre o contrato social e o uso do poder político. Foram os iniciadores do contratualismo, do direito internacional, do mercado liberal em pleno século XVI. No entanto, hoje são rechaçados do mundo intelectual e das referencias bibliográficas pela influencia do marxismo.

Se o socialismo como ideologia sempre defenderá que todos os seres humanos são iguais e que todos são bons, por si só são dois grandes equívocos. O homem não é maligno, porém se inclina facilmente a sua auto destruição e a destruição social. O que ele cria, como as estruturas sociais e políticas não são malignas, mas são imperfeitas, necessitando sempre de movimentos que visem ao aperfeiçoamento. Isso não quer dizer que devam ser destruídas. Quer dizer apenas que devem ser reorganizadas e aprimoradas temporalmente. Dizer, entretanto, que as estruturas sociais são malignas é outro equivoco, pois o ser humano criou as estruturas sociais não dentro de alguma malignidade, mas para o bem. O que foi e é criado deve sempre levar com consideração do bem comum, o respeito a liberdade humana. E a propósito, a descolonização das ideias, das coisas e da linguagem não trará a igualdade entre os homens. Só irá faze-los mais distantes da realidade. Perceber que a Igreja Católica apoia e até mesmo aprova tais percepções de mudanças sociais é inacreditável, e ao mesmo tempo inaceitável. Entretanto, constatamos seu intenso interesse e ações voltados para essa construção de mundo criticável e anticristão, na medida em que compartilha muito mais de afetos políticos e interesses obscurantistas maçônicos do que uma verdadeira referencia doutrinal católica. Traçamos aqui um pouco dessa experiência desastrosa do catolicismo libertário em pretender os portentos socialistas por meio da Teologia da Libertação no Brasil.

\section{CATOLICISMO LIBERTÁRIO COMO EXPERIÊNCIA HISTÓRICA NO BRASIL.}

O período da guerra fria ensejou novas mudanças no cenário político mundial e nas relações internacionais, 
afetando principalmente a América Latina. Tais mudanças situaram a Igreja Católica numa ação concreta pela Teologia da Libertação na luta pela terra, organizando os trabalhadores rurais para as ações de invasão de propriedades de terras e consequentemente, da concretização de uma justiça social enaltecida pelo catolicismo social. As ações da Igreja coincidiram com um contexto sóciopolítico na America Latina de crescimento dos movimentos sociais de esquerda, das guerrilhas armadas no campo, também da expansão de programas imperialistas norte americanos e russos ${ }^{4}$.

Com o chamado 'Milagre Brasileiro' em 1968, a experiência de crescimento econômico produziu avanços da modernização no campo, incentivos de produtividade do latifúndio e boas relações econômicas estabelecidas com o sistema capitalista liberal. $\mathrm{O}$ regime militar brasileiro continuou a marcha para o crescimento da economia liberal no país, bem como assegurou os altos investimentos financeiros gerando emprego e melhoria da macroeconomia.

$\mathrm{Na}$ contramão, os intelectuais marxistas começaram a se organizar nas universidades e espaços midiáticos levando

4 - LOWY, Michel. O Marxismo na América Latina: Uma antologia de 1909 aos dias atuais. São Paulo: Editora Perseu Abramo, 2003.

5 - WOLFORD, Wendy. 'Families, fields and fighting for land: the spacial dynamics of contention in rural Brazil'. In.: JOHNSTON, H. \& ALMEIDA, Paul. Latin American Social Movements: Globalization, Democratization, and Transnational Networks. New York: Rowman \& Littlefield Publishers, 2006. p. 163-176. Estes três fatores são apresentados ainda pela autora Wendy Wolford para a sua analise comparativa do MST no nordeste e sul do Brasil.

6 Ver: IZCUE, Julio Loredo. Teologia da Libertação: um salva-vidas de chumbo para os pobres. São Paulo: 2016.

7 - Igreja progressista: o termo empregado refere-se as mudanças adotadas pelos seminaristas e padres a cabo a tão sonhada revolução cultural advinda das teorias de Gramsci no país. Por sua vez, a Igreja católica progressista no empenho da Teologia da Libertação induziu grande parte do bispado e dos seminários a se posicionarem contrários à tradição católica e ao regime militar, gerando tensão social crescente em busca de mudanças ${ }^{5}$. Neste conjunto de mudanças do pensamento eclesiástico, o movimento social católico elabora a máxima de uma democracia cristã, proclamando sua militância social e política. Nascem daí os grandes movimentos como a JUC, Ação Católica e a Teologia da Libertação que se espalham pela América Latina ${ }^{6}$.

Assim, durante as décadas de 1960 á 1980 foram avassaladores os movimentos sociais através de um protagonista social capaz de otimizar as formas de ação coletiva no campo, ameaçando a então vigente estrutura democrática do país. Os membros progressistas da Igreja católica ${ }^{7}$, inseridos neste contexto não apenas organizaram os trabalhadores rurais, como fundaram as Comissões Pastorais da Terra (CPT), alicerçaram o Movimento dos Sem Terra, e também definiram as bases do Partido dos Trabalhadores, nascido obviamente dos interesses dos teólogos

que inovaram a pratica religiosa buscando, dentro de uma nova teologia projetos de ação social pelo ativismo político, militância e aproximação aos movimentos de esquerda comunista. Esta tendência do clero latino-americano foi constatada a partir dos anos de 1950 na América Latina. Assim, "Na Igreja progressista, agir era construir o Reino de Cristo executando o plano de Deus não no outro mundo, mas na Terra, agora" (SERBIN, 2008, p. 160). Cito um trecho de uma carta de D. José Maria Pires aos Militares na época quando indagado se era comunista. O bispo respondeu: 'a teoria da esquerda corre paralela com as ânsias da Igreja: a promoção do homem, mas de todos os homens'. PIRES, D. José Maria. Uma voz fiel à mudança social. São Paulo: Paulus, 2005. p. 167. 
progressistas católicos como Frei Betto, Frei Leonardo Boff e outros ${ }^{8}$. Como contínuo deste processo, a Igreja Católica dispõe sobre um discurso teológico-moral da promessa da terra para todos, fundada numa nova proposta de Evangelização e discussão sobre a terra ${ }^{9}$. Uma racionalidade progressista evolucionista que interpele e projeta o mundo real para um estado de abstração ilusória possível de bem-estar material e mental irreal e fantástico de um paraíso terrestre. É este discurso da promessa num tempo mítico e imaginário que movimentou os conflitos agrários desde a década de 1960 no Brasil. Mas, de onde vem esta teologia libertária? Onde ela bebe seus ensinamentos?

\subsection{Justiça Social Ou Revolução Social?}

A Doutrina Social da Igreja é um conjunto de princípios e normas de ação que constituiu parte do imaginário religioso do pensamento católico, decorrente de uma posição frente a modernidade que marcou a participação da Igreja num determinado período histórico. A pressão modernista concretizou-se na 'Rerum Novarum' em 1891, ampliando as possibilidades de diálogo entre a Igreja e seu contexto histórico moderno. Não obstante seu ultraconservadorismo ${ }^{10}$, a encíclica do Papa leão XIII foi um marco no 'retorno' da Igreja à sociedade, às comunidades e suas mazelas. Desta ação, inevitavelmente, a Igreja assentaria suas bases para um

\footnotetext{
8 - Ver: Arquivo Eclesiástico Prelazia de São Feliz do Araguaia. Fundo: Comissão Pastoral da Terra documentação avulsa. Conflitos no campo. Sem data.

9 - Ver o documento atual da Igreja de 1980: 'Os pobres possuirão a terra': pronunciamento de bispos e pastores sinodais sobre a terra. São Paulo: Paulinas, 2006; e CASALDÁliGA, Dom Pedro. Cartas Marcadas. São Paulo: Paulus, 2006.

10 - Ver: HOBSBAWN, E. A Era das Revoluções.
}

processo cada vez maior de abertura e aproximação com o pensamento comunista e marxista. A opção pelos pobres e pelas comunidades carentes como uma atividade intensa e mais social desenvolvia-se, abrindo as possibilidades de mudanças e de atitudes da Igreja progressista. Este comportamento inaugurou um campo simbólico, cujas representações discursivas configuram os elementos fundadores de uma Igreja brasileira mais participativa, e de caráter mais social. Ficava evidente que o processo de romanização desde o pontificado de Pio IX em 1846 sinalizava mudanças que culminariam em 1962 com João XXIII.

Um dos fundamentos principais da doutrina social reflete seu entendimento quanto a propriedade privada enquanto seu valor moral e coletivo, pelo simples fato de que a posse da terra pode ser considerada imoral e injusta quando poucos têm acesso a este direito, enquanto muitos passam necessidades materiais ${ }^{11}$. As encíclicas papais abordaram as questões sociais, levando em consideração o problema da propriedade tanto a partir da "Rerum Novarum" de Leão XIII, quanto depois pela "Mater et Magistra" de João XXIII. Também não podemos deixar de fazer menção ao condicionamento dado ao uso da propriedade, como se verifica na Encíclica "Quadragésimo Ano" de Pio XI. A idéia determina que a propriedade individual seja válida e legítima em sua função social.

Rio de Janeiro: Paz e Terra, 2001. O termo 'ultraconservadorismo' é empregado para analisar a postura da Igreja frente às ações de mobilização e conscientização trabalhista.

${ }^{11}$ Ver a carta de D. José Maria Pires: "A teoria da esquerda corre paralela com as ânsias da Igreja: a promoção do homem, mas de todos os homens". In.: PIRES, D. José Maria. Uma voz fiel à mudança social. São Paulo: Paulus, 2005. p. 167. 
Assim, a função social da propriedade representaria nada mais nada menos do que o reconhecimento de todo titular do domínio, que por ser um membro da comunidade têm direitos e obrigações com a sociedade. Ainda, o direito à terra se manifesta concretamente no poder de usála e usufruí-la. Porém, deve ser cuidada não como fonte de poder, mas como um bem coletivo. Porém, tudo isso está muito bem discutido na Igreja desde o século XVI com a Escola de Salamanca. O problema não é retirar a propriedade privada e transformala em coletiva. A propriedade privada não é o problema, uma vez que ela é um bem dentro do Direito Natural. Mas sim, criar propriedades comunitárias aos que não tem. Com isso eu determino oportunidades para os que não tem sem retirar direitos daqueles que já tem. Esse é o meio justo.

Mas a força revolucionária e os avanços do discurso progressista religioso católico marcariam seu início na década de 1960 com a figura de D. Hélder Câmara, D. Eugenio Sales no nordeste brasileiro. Ventos que iriam soprar apenas mais tarde na Conferência Nacional dos Bispos em Medellín e Puebla. Em vista de uma conjuntura histórica da Guerra Fria e a expansão dos interesses norte-americanos e também russos, os países latinoamericanos ressentiram-se de um empobrecimento econômico e do aumento da tensão entre trabalho e salários. Os documentos atestam a grande quantidade de desapropriação de terras e a alta concentração latifundiária que ocorre, principalmente pelas grandes multinacionais como as Casas Pernambucanas, as montadoras como Mercedes Bens e vários bancos que ao

12 - Ver: Arquivo Eclesiástico da Paraíba. Fundo: Conselho de Pastoral. Relatório da CPT em 1998; e Arquivo Eclesiástico Prelazia de São Feliz do comprarem as fazendas desapropriavam os trabalhadores rurais, sem direitos trabalhistas. De outro lado, a influência comunista russo e chinês em movimentos armados no campo $^{12}$. O catolicismo progressista aliou seu discurso ao contexto social como oportunidade histórica. O imaginário religioso popular sentiu-se revigorado pela proposta transformadora e socializada frente a doutrina social. Atestanos tal coisa quando D. Hélder tomou sua atitude mais contundente de apoio aos pobres, quando de uma enchente que assolou o Nordeste, desabrigando e desesperando centenas de camponeses e moradores de bairros pobres do Recife e imediações. A partir daí, os trabalhadores rurais e grande parte da juventude da época se organizariam em grupos associativos liderados pela Igreja. A mudança estaria concretizada, como já foi dito, em Medelín e Puebla.

Portanto, uma época importante para a conscientização política no Brasil com o aumento dos movimentos sociais tanto urbanos, quanto no campo. Dentre estes movimentos, os estudantes estavam movidos pela crescente participação política e incentivos de organização da UNE desde 1962, quando lançam sua música "O Subdesenvolvido", não faltaram como garantia de sua representação e participação como membros integrantes de um processo de crescimento de uma cultura política democrática no país. A solução foi dada pela Aliança para o Progresso elaborada pelos norte-americanos, principalmente como resposta às crises no meio rural. A proposta de Reforma Agrária norte-americana teria sido louvável, se concretizada. Em vista disto, a truculência

Araguaia. Fundo: Comissão Pastoral da Terra documentação avulsa. Conflitos no campo. Sem data. 
das decisões políticas acirrou ainda mais os conflitos rurais e os trabalhadores despejados das Fazendas começaram a aparecer nas listas de documentos arquivados das Arquidioceses ${ }^{13}$.

O período representado retrata um contexto de crescimento dos imperialismos norte-americano e Russo na AméricaLatina: o primeiro pelas atividades econômicas do desenvolvimentismo otimista na visão de Rostow, e o segundo pelas atividades de sustentação e financiamento de guerrilhas armadas no campo na tentativa de minar o capitalismo liberal. $\mathrm{O}$ acirramento entre as propostas de modelos econômicos de desenvolvimento para o Brasil disputou o palco das ações entre o pressuposto liberal de Rostow e as novas discussões elaboradas por um nacionalismo de esquerda de Celso Furtado (então pertencente ao grupo da CEPAL) e do seu oposto Roberto Campos. A capacidade de desenvolvimento econômico adequado às normas de Rostow veio de encontro às perspectivas normativas da economia dos países latino-americanos tendo como respaldo a expansão da economia norte-americana. A CEPAL dentre outras coisas buscava na reforma agrária um pressuposto para a solução da pobreza e de outros males sociais para o país tendendo a uma social democracia. $\mathrm{O}$ debate pairava sobre a reforma agrária como condição primeira para que o país superasse $o$ processo de subdesenvolvimento econômico.

A proposta de desenvolvimento econômico atrelado aos interesses do

\footnotetext{
13 - Como exemplo: Arquivo Eclesiástico da Paraíba. Fundo - Relatórios da CPT. Data: 1966. 14 - Arquidiocese de Mariana. Arquivo Episcopal da Cúria de Mariana (AECM). Fundo de correspondências. Cartas de D. Geraldo de Proença Sigaud.
}

capitalismo liberal tornou-se concreta a partir do governo JK, definindo-se pela escolha de integrar a economia brasileira aos interesses do liberalismo econômico, através do Plano de Metas e outras formas de negociação de intercâmbios de interesses políticos-econômicos do então governo Juscelino Kubistchek.

Entretanto, o período emblemático de João Goulart e sua afeição pelo comunismo causava temores em parte do clero. Uma correspondência de D. Geraldo Sigaud (Arcebispo de Diamantina) para D. Antônio de Castro Mayer (Bispo de Campos do estado do Rio de Janeiro) enfatizava que a ideia de uma reforma agrária, cujo conceito de propriedade coletiva não era apenas marxista, mas revolucionária: "confiscatória e comunista"14. Por volta de 1963, a cúpula de bispos liderada por D. Geraldo Sigaud e parte do alto comando militar começaram a articular um golpe de estado necessário, que levaria à tomada dos militares ao poder ${ }^{15}$. Com os governos militares, a partir de 1964, a Igreja progressista e os movimentos de guerrilha intensificaram as suas formas de violência, promovendo os conflitos no campo e invasões de terras produtivas ou não. $\mathrm{O}$ aumento da violência no campo torna-se latente até o período da 'abertura democrática' em fins da década de $1980^{16}$.

\subsection{Igreja, questão agrária e a revolução.}

Além das investidas contundentes de padres no campo, algumas atuações

\footnotetext{
15 Arquidiocese de Mariana. Arquivo Episcopal da Cúria de Mariana (AECM). Fundo de correspondências - Documentos avulsos.

16 - Arquivo Eclesiástico da Paraíba. Fundo: Conselho Pastoral - Pastoral Rural - CPT. Data: 1963-1998.
} 
foram importantes no período como a criação das CEBs (Comunidades Eclesiais de Base) incentivadas pela Conferência Episcopal de Medellín ${ }^{17}$ e atuando sob a direção dos bispos progressistas, e a sindicalização do trabalhador rural também promovida pelos líderes católicos no campo, que ameaçava a incomodar as elites rurais brasileiras ${ }^{18}$. Porém, as formas de conscientização política no campo serão negadas pelo poder estatal, mesmo com a presença 'pacífica' da Igreja como liderança.

Com a proposta da Teologia da Libertação de retorno às 'fontes', de uma renovação teológica de cunho social, o confronto da Igreja com novas realidades sociais, a Ação Católica, a inserção no mundo da cultura intelectual, o processo das 'ciências humanas' e os novos métodos histórico-críticos na leitura bíblica foram configurando um novo perfil à Igreja Católica pré-conciliar, que afetou principalmente os países da América Latina.

A Igreja no país foi se articulando ao nível da criação da CNBB e de uma conseqüente pastoral mais orgânica e efetiva, marcando um novo estilo de atuação na dimensão política e social. A atuação centrada nas regiões e localidades específicas organizou-se em atividades intensas a partir de lideranças de grupos leigos engajados e padres com efetivo empenho social. Com a criação da Arquidiocese de Goiânia foi nomeado seu primeiro arcebispo, o então bispo de Aracaju, D. Fernando Gomes de Santos, e

17 - Sobre as CEBs ver: PIRES, D. José Maria. Uma voz fiel à mudança social. São Paulo: Paulus, 2005. p. 161.

18 - Ver a documentação: Arquidiocese da Paraíba. Arquivo Eclesiástico da Paraíba. Fundo: Conselho dois anos depois, a prelazia já projetava um 'plano piloto de reforma agrária'.

O conflito ideológico havido dentre D. Fernando Gomes dos Santos e D. Castro Mayer revelam as tendências e as tensões pró e contra a reforma agrária no país ainda na década de 1960. Este conflito não era especificamente 'eclesiástico', mas mostrava a natureza do clero brasileiro. A questão principal que norteava as discussões acirradas era o conceito de 'direito de propriedade', que induzia a repensar nos termos da teoria marxista e seus respectivos desdobramentos filosóficos, históricos, culturais, políticos e até econômicos. Tal indução, inclusive, intensificou e formulou politicamente a posição e a presença da Igreja Católica na questão agrária, pela pastoral de D. Inocêncio em 1950, condicionada à Doutrina Social. Os anos que se seguiram foram fecundos para a formulação de uma concepção de reforma agrária 'sob os postulados do cristianismo católico social'. A reação foi a formação da Aliança para o Progresso.

D. Hélder Câmara, considerado um bispo progressista (e comunista), criticou vorazmente através da imprensa norteamericana e francesa a Aliança para o Progresso instituída na América Latina, e suas repercussões nefastas aos pobres trabalhadores no Brasil, principalmente o trabalhador rural ${ }^{19}$. Tudo isto formou a complexa teia histórica que configurou uma visão de uma Igreja Católica comunista, progressista ou de esquerda marxista para o Brasil, o que em muito subtraiu as possibilidades de diálogo

\footnotetext{
Pastoral - Pastoral Rural - CPT. Relatórios das atividades da Pastoral da Terra na Arquidiocese da Paraíba de 1963 à 1988.

19 - Instituto D. Hélder Câmara. Arquivo/Fundo: Histórico da Operação Esperança - documentários.
} 
interno e a soma de forças com outras organizações sociais pró-reforma agrária, devido ao seu conflito e embate essencial próprio ao seu contexto. Moralmente condicionada, a participação de D. Hélder Câmara e D. Fernando na formulação do Estatuto da Terra por volta de 1960 é uma das expressões históricas da Igreja Católica naquele tempo. Contextualizados pela ação política da anticomunista, que se articulava em vista do golpe militar de 1964, consciente ou não dela, buscava-se o setor progressista do episcopado para empreender uma redefinição fundiária no país. Uma ação de reforma agrária com a mediação da política oficial do governo e dos líderes da Igreja.

Portanto, a reforma agrária (dita cristã) não significaria a anulação da idéia e da representação do poder inerente à propriedade, mas a possibilidade de que todos pudessem ser proprietários de suas terras e, não menos importante, da sua propriedade privada justificada pela sua 'função moral e social (relevante ao trabalho). O que não está claro é como esta propriedade se caracterizava: coletiva? Social? Ou privada de uso coletivo? E, por isso se entende outros empreendimentos de ação orientadora da Igreja Católica passando pela organização de sindicatos rurais, da organização das romarias locais e da atuação dos trabalhadores em associação aos Partidos Políticos. $^{20}$ Tendo uma orientação pedagógica desde Leão XIII, procurou-se articular, numa perspectiva de 'nova cristandade combativa', os trabalhadores do campo. Frentes Agrárias (em Goiás a FAGO - Frente Agrária Goiana) desencadeavam em ampla sindicalização rural, num sindicalismo

20 - Arquidiocese da Paraíba. Arquivo Eclesiástico da Paraíba. Fundo: Conselho Pastoral - Pastoral Rural - sujeito á Doutrina Social da Igreja. Outro elemento também sugestivo neste âmbito, e não suficientemente abordado pelos historiadores, foi a participação que a Igreja Católica na formulação das leis trabalhistas, segundo PAIVA (1985).

A 'ação social' da Igreja Católica no Brasil, na região Centro-Oeste ou em Goiânia, viveu, na década de 1950 a meados da década de 1970, uma dupla perspectiva: de um lado, perduravam e criavam-se obras sociais no estilo 'tradicional'; de outro, emergiam novas 'ações sociais' e atuações pastorais (Ação Católica Especializada). Se para o Estado isso foi problema, para a Igreja Católica inicia-se um 'problema de sentido', que remete à sua própria identidade e a reformulações de suas justificativas para sua 'ação social'.

Também a Ação Católica especializada, e ainda com maior intensidade, caracterizou a 'ação social' da Igreja Católica no Brasil, na década de 1960. A partir daí a questão agrária ganhou um realce mais polêmico, porque passou a ser tratada de modo mais intenso e numa perspectiva mais conflitiva. $\mathrm{O}$ MEB (Movimento de Educação de Base) foi um dos espaços de presença da Ação Católica Especializada. Com tais empreendimento a Igreja inseriu-se no mundo da comunicação social e nas propostas de 'educação de massa' que, gradativamente, foi se transformando num sentido mais amplo, argumentando seus projetos aos interesses de mudança social e conscientização política, mediante o apostolado no campo, principalmente.

Vejamos alguns exemplos de experiências no processo de reforma

CPT. Relatório das atividades da Pastoral da Terra na Arquidiocese da Paraíba em 1988. 
agrária, como na fazenda Conceição, desde a doação destas terras à Arquidiocese de Goiânia até o assentamento dos agricultores e, por fim, o 'expirar' desta 'experiência' que não daria certo. Iniciada em 1961 a experiência de assentamentos rurais pela fazenda Conceição, em 1966 entraria em crise por motivos econômicos e até de liderança interna. Entretanto, uma das maiores experiências de ação pastoral em áreas urbanas e rurais seria presenciada em 1965, pela Operação Esperança com a presença de D. Hélder Câmara em Recife ${ }^{21}$. As propostas de ação rural tornaram-se concretas em 1974 quando a $\mathrm{OE}$ (Organização Esperança) comprou três engenhos e assentaria algumas famílias pernambucanas na terra. $O$ Engenho de Piranga, o de Taquari e o Guaretema, ainda em atividade, tiveram a intenção de concretizar um Plano de Ação emergencial e tentar a implementação de uma propriedade coletiva. Ainda como objetivo dos assentamentos, D. Hélder vislumbrava a integração sócio-econômica do homem ao seu habitat e ao mercado de trabalho ${ }^{22}$. O trabalho previu tanto o assentamento, quanto o financiamento previsto às famílias rurais, que durou até os governos militares.

Enquanto a reforma agrária foi o ponto fulcral das discussões, a ação pastoral quanto à questão agrária lançou suas raízes na sociedade no começo da década de 1970, sustentando as ações populares da JAC até a década de 1980,

21 - Instituto D. Hélder Câmara. Arquivo/Fundo: Histórico da Operação Esperança. Documentos: estatutos.

22 - Instituto D. Hélder Câmara. Arquivo/Fundo: Histórico da Operação Esperança. Documentos: estatutos.

23 - JUC (Juventude Universitária Católica), JEC (Juventude Estudantil Católica), JAC (Juventude Agrária Católica), e o MEB (Movimento de Educação de Base).

24 - Ver: BOTAS, Paulo César. A Benção de Abril: conjuntamente a outros movimentos católicos, tais como a JUC, JEC e o MEB ${ }^{23}$, que incrementavam a realidade brasileira, a partir de discussões e oportunidades históricas defendias pela mudança política e econômica. As arquidioceses do nordeste movimentaram-se primeiro, mesmo por que as Ligas Camponesas de Francisco Julião já tinham se organizado no Nordeste com a criação do Engenho Galiléia em 1955 na cidade de Pernambuco ${ }^{24}$. A partir destas experiências o Rio Grande do sul contou com a representação de D. Ivo Lorscheider e sua atuação e apoio aos projetos da Operação Esperança de D. Hélder. Entretanto, as experiências do sul e do nordeste tiveram desfechos diferenciados. Atualmente o desenvolvimento econômico dos assentamentos rurais no Sul, principalmente em Santa Maria podem ser diferenciados e com grande sucesso na proposta da economia solidária do MERCOSUL. A interação entre Igreja e assentamentos rurais nesta região do país ainda e freqüente ${ }^{25}$.

Em 1975 foi criada a CPT (Comissão Pastoral da Terra) como fruto deste despontar das tensões, da movimentação social e das questões agrárias estruturais do país. Como atesta Frei Anastácio “desde 1969 o movimento ia se expandindo, juntamente com a evangelização e conscientização dos camponeses"26. As denúncias da CPT do

memória e Engajamento Católico no Brasil: 1963-1964. Petrópolis, 1983. O autor realça atuação das Ligas Camponesas lideradas por Julião membro partidário do PSB. Porém, com o desenvolvimento das lideranças católicas no campo o conflito entre as duas ideologias seria iminente.

25 - Arquivo Eclesiástico da Arquidiocese de Santa Maria. Documentação não arquivada.

26 - Arquivo Eclesiástico da Paraíba. Fundo: Conselho Pastoral - Pastoral Rural - CPT. Data: 1963-1998. 
nordeste atestam tanto o uso do trabalho escravo, quanto das formas de pistolagem do campo enfrentados pela Arquidiocese de Recife e Olinda e da Paraíba. Em contrapartida, todas essas formas de intervenção social, visibilidade do campo, contestação ao latifúndio e direito á terra também foram muito além dos ensinamentos do Evangelho e da moralidade cristã ${ }^{27}$. Houve um engajamento político revolucionário que orientou os homens do campo para seus direitos que são básicos e inegáveis, através de invasões de propriedade, paralizações de rodovias, uso de cartilhas para o ensinamento, as romarias da terra, os encontros persistentes dos líderes e suas áreas de comando, leituras afins e atuação direta dos padres e agentes pastorais no meio do conflito e nas zonas de perigo, mesmo ameaçados de morte, como o caso da Irmã Doroty Stang, o frei Anastácio e o padre Luiz Couto ${ }^{28}$. A crença era que se poderia alcançar o estágio do comunismo destruindo a base primeira do sistema mais perverso já criado pelo homem. O capitalismo iria desabar quando seu tronco vital, que era o latifúndio, fosse cortado. Depois outros pilares ruiriam, como grandes instituições capitalistas de mercado, bem como o próprio imperialismo norte-americano.

A meta, então, era capacitar a classe trabalhadora rural para o alcance de uma reforma agrária de fato, visando a melhoria das condições trabalhistas, pela organização e alcance das formas sindicais do campo. Conjuntamente a estes pressupostos, a ideia de 'libertação'

27 - Ver: Arquidiocese da Paraíba. Arquivo Eclesiástico da Paraíba. Fundo: Conselho Pastoral Pastoral Rural - CPT. Data: 1963-1998.

28 - Arquidiocese da Paraíba. Arquivo Eclesiástico da Paraíba. Fundo: Conselho Pastoral - Pastoral Rural - favoreceu a organização sindical, os movimentos sociais, as vanguardas e a conscientização política dos grupos rurais. Com o discurso de libertação da exploração, libertação da miséria e das formas opressoras do capitalismo, a Pastoral da Terra tem sua importância no país pela tentativa de resolver a questão da terra, a partir do desenvolvimento teórico da idéia libertação da miséria e da exclusão social.

Em 1985 a Comissão Pastoral da Terra (CPT) lança o seu "Plano Nacional de Reforma Agrária" para o país, onde fica clara a intensão e ideia de uma reforma agrária a partir da Teologia da Libertação centrada na "legalização das ocupações de terras, desapropriação de empresas rurais, impedir o latifúndio como elemento lucrativo e punir os assassinatos no campo" 29 .o documento foi elaborado pelos líderes da CPT conjuntamente com os sindicatos rurais na década de 80 sendo um projeto deliberado de desmonte dos recursos econômicos da nação alicerçados na produção agrícola, destruição das empresas economicamente sustentáveis e produtivas do campo e da clara tentativa comunista de romper com o capitalismo liberal. Nota-se, portanto, que atrás do discurso da miséria do camponês está um certo objetivo de desmontar os interesses do grande capital liberal, romper com o capitalismo e promover a coletivização do campo. $\mathrm{O}$ documento não aponta nenhuma forma de produtividade das pequenas propriedades, não direciona a produção agrícola ao mercado, não conduz o pequeno proprietário a nenhum benefício do

CPT. Data: 1963-1998.

29 - Arquidiocese de Maceió. Arquivo eclesiástico da Arquidiocese de Maceió: Fundo CPT. Plano Nacional de Reforma Agrária, 1985. 
mercado liberal. Um projeto comunista para o campo com a pretensão revolucionaria instruído e direcionado por potencias socialistas. Consequentemente, a movimentação social causada pela repercussão dessa proposta gerou um aumento dos conflitos agrários, oriundos de uma metodologia do combate no campo pelas invasões de terras, sob a orientação da libertação do julgo dos opressores, como conceito presente na Doutrina Social.

A repercussão da Pastoral da Terra e da mobilização social em torno do problema do campo já havia alcançado níveis de discussões avançados na sociedade brasileira, inclusive no meio eclesiástico. Os movimentos sociais com suas lideranças religiosas no campo serviam a um projeto bem maior que lutar pela posse de terras. Eles pretendiam um maior enfrentamento com os militares e com o imperialismo norte-americano. Mas, a verdade é que, enquanto os movimentos agrários revolucionários tentavam combater o grande capital, o regime militar possibilitou uma prática de reorganização da estrutura fundiária favorável ao desenvolvimento capitalista liberal e a modernização do campo como base e manutenção das condições de poder no país. A ideia era a produção de grãos e beneficiamento do solo com grandes tecnologias agrícolas. Assim, os movimentos sociais a partir da orientação da Igreja progressista com relação ao conflito do campo, da criação da Pastoral da Terra, dos discursos e memórias de D. Pedro Casaldáliga ${ }^{30}$ e do enfrentamento de grupos leigos e religiosos nas zonas de conflito ao transformaram-se numa ação política aberta contra o capitalismo liberal e o imperialismo norte-americano perdiam

30 - CASAldÁligA, Dom Pedro. Cartas seu foco de ação que eram os pequenos proprietários do campo. Ou seja, toda a orientação política da Igreja gerou um movimento organizado no campo, declaradamente revolucionário e comprometido com interesses socialistas e globalistas.

\section{A ONU, OS GLOBALISTAS E O CIMI.}

A partir dos anos 90, com a abertura da economia russa pela Glasnost e a Perestroika de Mikhail Gorbatchov e a queda do Muro de Berlim, as mudanças internacionais projetavam-se cada vez mais numa prospectiva dinâmica do progressivismo, tendo a ONU como seu grande porta voz. Essas transformações afetariam também a América Latina e a dinâmica do catolicismo social, variando seu objetivo e foco de atuação. A nova reconfiguração internacional projetou seus interesses novamente no Brasil e em áreas latino-americanas, onde as riquezas minerais começaram a ser disputadas também pela expansão imperialista do mundo comuno-socialista. Reservas indígenas inteiras alocadas nos vagos territórios com suas potências minerais, como o nióbio, começaram a ser identificadas pelo Brasil como a Reversa indígena Raposa Serra do Sol em Roraima. Palco de um conflito movido por grandes interesses estrangeiros como a Rússia e a ONU, a Igreja iria se pronunciar em 2008 de forma vaga e superficial.

Assim, além da atuação da CPT para a área campesina no país, o CIMI (Conselho Indigenista Missionário) tem sua importância no fato da realização dos espaços reservados aos agentes de interesse da Igreja progressista na segunda metade

Marcadas. São Paulo: Paulus, 2005. 
do século XX: o índio em terras de fronteira. A 'Operação Upatakon 3',31 realizada pela polícia federal em 2008 durante o governo Lula revelou uma estratégia política do governo petista aliado aos interesses globalistas. Em 2005 Lula homologou as faixas de terras contiguas a Reserva adentrando os interesses de plantadores de arroz na região. O conflito foi provocado pela expansão dessas terras como reservas indígenas retirando os plantadores de arroz e cedendo aos índios. Qual interesse? Ampliar a faixa de terras conhecida como 'Corredor Triplo A' capaz de gerar alcançar a fronteira com a Venezuela e território das FARC.

O discurso superficial da Igreja progressista sobre os conflitos e sobre os interesses internacionais foi de acordo com o projeto político do governo Lula. O olhar cego para os acontecimentos reais, frente os projetos políticos de esquerda, superava as reprovações da Igreja no Brasil. O CIMI tratava de preservar as reservas indígenas e seus costumes apenas. De certa forma, os habitantes da região da fronteira no país ainda possuem hábitos característicos de tradições indígenas milenares ainda preservados, mas que são constantemente ameaçados e interpelados por interesses das multinacionais de diversos países como China, Rússia, França, Alemanha, etc. Em muitos casos, a atuação da Igreja tem sido ambígua na profusão daquilo que deve preservar como área de interesse nacional.

Para discutir da disposição do CIMI e a defesa dos índios devemos nos reportar a dois fatores: primeiramente "o CIMI foi fundado em 1972 como produto da

\footnotetext{
31 - Ver:

http://g1.globo.com/Noticias/Brasil/0,,MUL464471 $-5598,00-$

ENTENDA+O+CONFLITO+NA+TERRA+INDIG ENA+RAPOSA+SERRA+DO+SOL.html
}

Conferência de Barbados e cuja missão era atacar toda a concentração de evangelização da igreja Católica desde a descoberta das Américas"32. O segundo ponto está numa experiência histórica no centro-oeste do Brasil. Uma onda de migração territorial no interior do país que ganhou significado para a região central entre as décadas de 70 e 80 com os gaúchos invadindo as áreas do interior como Goiás, Tocantins, Altamira, etc. Isto de certa forma trouxe uma nova re-alocação populacional oprimindo as tribos indígenas e destruindo certos costumes, com a modernização e urbanização do local. É uma versão moderna da conquista desenhando novos pontos de equilíbrio e de conflito entre os habitantes indígenas e os que chegavam de outras áreas do país.

Lutando entre as ondas migratórias internas e os interesses internacionais, os últimos trinta anos revelaram não apenas uma resistência indígena frente aos abusos de poder de determinadas ONGs e da voracidade da terra e seus bens minerais, mas a extensão da riqueza e do descontrole nacional dessas áreas vulneráveis. O ambiente de conflito ampliava-se com as grandes empresas como grilagem e os grandes proprietários de terras como elementos significantes de expansão de interesses internacionais chineses, norteamericanos, franceses e russos nestas áreas de fronteira. Em contraposição, o entendimento das lideranças religiosas pesou na definição das ações políticas frente aos abusos de poder e leniência da justiça brasileira. A atuação da Igreja

\footnotetext{
Acessado em 24 de novembro de 2019.

32 - Ver: CARRASCO, Lorenzo. CIMI: o filho da mentira. Rio de janeiro: Capax Dei, 2016. P. 30.
} 
passava por uma transição de valores filosóficos das referências ideológicas antiimperialistas de D. Pedro Casaldáliga ao enaltecimento pagão do CIMI (Conselho Indigenista Missionário) da desconstrução de evangelização indígena colonial.

A ideia da Igreja progressista era preservar o índio em sua forma natural inclusive seus costumes religiosos, desconstruindo as referências católicas desde o descobrimento português, na suposição de que os esforços da luta da terra se concentravam apenas na referência da identidade e preservação do índio. Enquanto as terras nas áreas de fronteira vivem a pressão de interesses de ONGs estrangeiras para o controle territorial do lugar, a Igreja se posiciona incólume aos desafios de forma superficial na defesa do território nacional e das reservas indígenas como inseridas neste contexto geográfico. Realmente, a proposta do CIMI está inserida numa dimensão de atacar não apenas o capitalismo, como outrora, mas agora destruir a ocidentalização naquilo que foi construído pela própria Igreja na tentativa de resgatar o indígena como um ente natural, sem aculturação.

Em 1983 a ONU criou a comissão mundial sobre meio ambiente e desenvolvimento, conhecida como Comissão Brundtiand, comandada pela primeira ministra da Noruega Gro Harliem Brundtiand, cujo interesse maior era mapear e controlar as áreas mais ricas em minérios como o nióbio. A maior investida de ONGs estrangeiras se deu em reservas indígenas no Brasil, na faixa conhecida como 'Cabeça de cachorro' e o 'Corredor Triplo A'.

\footnotetext{
33 - Folha de São Paulo. 24 de abril de 2005. Pp: 12 e 13 .
}

Os governos Lula e Dilma ambos comprometidos com a agenda de esquerda e promotores do Foro de São Paulo como organização capaz de implementar a 'Pátria Grande' na América Latina, nunca deixaram de negociar a 'preço baixo' com os interesses russos e chineses para a exploração desses minerais em reservas indígenas. $\mathrm{Na}$ verdade, a demarcação de reservas indígenas começou a ser implementada em 2015 de forma contundente. Dilma homologou as reservas indígenas numa região das maiores jazidas minerais do mundo: o 'Corredor Triplo A'. Uma política de controle territorial brilhante. $\mathrm{O}$ governo concedia as terras aos índios, depois deixava entrar centenas de ONGs nas reservas homologadas, cujos interesses estavam de acordo com o grande projeto da esquerda para a América Latina, e por fim manobravam os índios como fantoches nessa transação internacional.

O que está por traz dessa política de reservas indígenas nos governos Lula e Dilma? E por que a Igreja progressista compactuou com esse projeto? Em 2005 uma declaração do governo Lula revelaria que a pressão internacional para as reservas indígenas era fato real ${ }^{33}$. Um interesse não apenas voltado à extração de matérias primas como o nióbio, mas também promover o desmembramento destas áreas indígenas em territórios supranacionais. Isto poderia ser perfeitamente visível quando a vida indígena estava completamente deslocada da participação nacional ${ }^{34}$.

A mudança de repertório da ação da Igreja foi completamente transformada a partir do avanço dos governos de esquerda na América Latina, e com uma nova

\footnotetext{
34 - Ver: CARRASCO, Lorenzo. CIMI: filho da mentira. Rio de Janeiro: Capax Dei, 2016.
} 
postura do Vaticano frente ao avanço e orientação crescente das mudanças internacionais. Um corpo doutrinário e evangélico concentrado no 'Evangelho das bem-aventuranças' para os pobres em comum acordo com as pautas globalistas do meio ambiente. Portanto, a $18^{\mathrm{a}}$. reunião da CNBB (Conselho Nacional dos Bispos do Brasil) evocava os problemas da terra, ao anúncio desta 'nova proposta de evangelização ambientalista'. Mesmo com sua repercussão no país, os cuidados da Igreja foram eloqüentes quanto a vigente doutrina da Igreja. Ressaltamos o cuidado com a utilização deste conceito e outro que traduza a liberdade positiva. Necessitamos de uma abordagem mais apurada e crítica neste sentido, oportunizada em outro momento.

Assim, temas como globalização ${ }^{35}$, agressão ao meio ambiente e mercantilização da terra foram eloqüentes como debates na reunião, gerando uma proposta atual sobre a questão da terra, e a postura do clero latino-americano, que passa a ser não apenas regional, mas planetária, global. Esta nova consciência insere-se nas propostas da Teologia da Libertação e sua nova evangelização dos pobres em reservas indígenas. ${ }^{36}$

\section{CONCLUSÃO}

Basicamente o problema da terra permaneceu o mesmo no Brasil. Ainda existe, de forma oscilante e tênue, uma permanência dos conflitos agrários causados, por vezes, pelas invasões de terras condicionada por uma orientação

\footnotetext{
35 - O conceito de Globalização é entendido como um 'conjunto de transformações na ordem política e econômica mundial que vem acontecendo nas últimas décadas. $\mathrm{O}$ ponto central da mudança é a integração dos mercados numa "aldeia-global", explorada pelas grandes corporações internacionais'.
}

militante no campo. Este repertório de luta por uma classe de trabalhadores rurais mesmo enfraquecido em sua luta por uma reforma agrária que atravessou os anos dos governos neopopulistas de esquerda do país reserva-se a sua sobrevivência pela CPT e a atuação da pastoral no campo. Mesmo cambaleante e sem solução para muitas famílias e trabalhadores rurais, que caminharam muitos anos com os sonhos encantadores da Igreja, ainda permanece um resquício de movimento social ora aqui ora ali em invasões e saques de propriedades privadas no campo. As formas de orientação política do homem rural, a conscientização dos problemas agrários e a movimentação do trabalhador em direção aos seus direitos a terra e a sua produção foram lançadas pela Igreja progressista no campo foram aos poucos mudando de sujeito para abraçar as reservas indígenas.

A Igreja progressista tem cada vez mais silenciado sobre uma possível resolução dos conflitos agrários, atuando conforme um projeto de interesses estrangeiros que beneficie os governos de esquerda. $\mathrm{O}$ abandono de um programa de reforma agrária, até então, pauta da luta pela terra revelou tanto a incapacidade no discurso comunista clerical, quanto numa prática efetiva para os pobres trabalhadores rurais. O que importava era a derrota do imperialismo norte americano e do capitalismo liberal. Essa mudança de programa de atuação da CPT para o CIMI evidencia um novo modelo de conduta da igreja progressista para a América Latina.

(IANNI, 1997).

36 - Ver o documento atual da Igreja em 1980: 'Os pobres possuirão a terra': pronunciamento de bispos e pastores sinodais sobre a terra. São Paulo: Paulinas, 2006. 
Entrementes, a questão indígena não é nova na história. Está entranhada no discurso de uma agenda mundial desde os anos de 1950 com um ataque direto ao Estado Nação e na pauta uma religião panteísta. Nada de novidade quando vemos o Sínodo da Amazônia e os seus líderes coligados a uma Igreja progressista, como D. Cláudio Hummes.

O eco progressista que a Igreja reproduz hoje está centrado em interesses da nova esquerda certamente. A mudança foi a retomada das formas de contradição do sistema capitalista promovidos não por um sujeito como a classe trabalhadora rural, mas agora como um movimento dos excluídos índios. Essa pauta dos movimentos sociais: negros, índios e homossexuais é a tentativa de revigoramento da esquerda progressista na América Latina tendo como suporte a ala social da Igreja Católica.

\section{REFERÊNCIAS BIBLIOGRÁFICAS:}

\section{Fontes Primárias:}

\section{Biblioteca da PUC - São Paulo.}

1- Documento de Puebla - Texto Oficial da CNBB - Ed. Vozes Ltda. -

Petrópolis - RJ - 1979

2- Carta Pastoral de João XXIII "Mater Et Magistra". Paulinas: São Paulo, 1961.

3- Carta Pastoral de João Paulo II: "Solicitudo Rei Socialis". Paulinas: São Paulo, 1988

4. Documentos da CNBB. Tomo. 8503. 1978.

Documentos da CNBB. Tomo. 8503.

\section{Arquivo da Prelazia de São Félix do} Araguaia / Xingu:
1. Quadro da Violência contra os trabalhadores rurais e seus aliados na região da Prelazia de São Félix do Araguaia no Ano de 1991.

2. Documentos da CNBB, 69: Exigências evangélicas e éticas de superação da miséria e da fome.

3. Documentos da CNBB. Para uma melhor distribuição da terra: o desafio da reforma agrária.

4. O Projeto Esperança: a construção da economia solidária no Brasil, 2006. Anais de Seminário.

5. Documentos: Comissão Pastoral da Terra. Conflitos no Campo. Brasil, 2005.

6. Documentos: Comissão Pastoral da Terra: Violação dos Direitos Humanos da Amazônia: conflito e violência na fronteira paraense.

7. Plano INCRA/MDA. Para a erradicação do Trabalho Escravo. 2005.

8. Carta enviada ao Para em 1990 contendo uma linha de assinaturas contra a fazenda do Banco Bamerindus na região.

9. Lista de ameaçados de morte em 2004 (contém o nome da Ir. Doroty Mae Stang).

10. Folhetos explicativos para a população sobre o problema do trabalho escravo.

11. Relação de recortes de jornais que datam de 1980 a 1990, quanto ao problema do Frei Leonardo Boff e sua expulsão da Igreja.

12. Jornal Alvorada de 1995. Assunto referente às comunidades indígenas.

13. Arquivo em CD-Room contendo fotos e parte do acervo da Prelazia de São Félix do Araguaia.

\section{Arquivo Eclesiástico da Paraíba.}


Fundo: Conselho Pastoral:

correspondências; eventos.

Fundo: Comissão Pastoral da Terra -

Relatórios da CPT, listas de

assentamentos, eventos, romarias,

relatórios administrativos.

Correspondências diversas.

\section{Arquivo Episcopal da Cúria de}

Mariana.

Fundo: Cartas pastorais: Documentos da CNBB; cartas pessoais.

Fundo: Pastoral da Terra. Arquivo 07:

Gaveta 01. Pasta 06.

Fundo: correspondências.

Correspondências pessoais de bispos.

(documentação não autorizada).

5. Arquidiocese de Olinda e Recife.

Instituto Dom Hélder Câmara.

Fundo: Operação Esperança.

Correspondências e estatutos.

Documentários, fotos e depoimentos

pessoais em arquivos. Jornais da época.

6. Arquidiocese de Maceió.

Fundo: CPT- Comissão Pastoral da Terra.

Documentos avulsos.

\section{Bibliografia:}

ÁLVAREZ, Gloria \& KAISER, Axel. O embuste populista: porque arruínam nossos países, e como resgatá-los. São Paulo: LVM, 2019.

ALVES, M. A Igreja e a Política no

Brasil. Brasiliense, 1989.

AMADO, Wolmir Herezio. A Igreja e a Questão Agrária no Centro-Oeste do Brasil, 1950-1968. Dissertação de Mestrado em História - UC Goiás. 1996.
ARENDT, Hannah. Da Revolução.

Brasília: UNB, 1994.

BOFF, Leonardo. Nova Evangelização

Perspectiva dos Oprimidos. Editora:

Vozes, 2001.

BOTAS, Paulo César. A Benção de Abril: memória e Engajamento Católico no Brasil: 1963-1964. Petrópolis, 1983.

CARRASCO, Lorenzo. CIMI: filho da mentira. Rio de Janeiro: Capax Dei, 2016.

CASAldÁligA, Dom Pedro. Cartas marcadas. São Paulo: Pulus, 2005. DEWAR, Elaine. Uma demão de verde: os laços entre grupos ambientais, governos e grandes negócios. Rio de Janeiro: Capax Dei, 2012.

DUSSEL, Enrique. De Medellín a Puebla. México, 1979.

FIORI, José Luis. Desenvolvimento e Política externa. In.: Jornal Valor Econômico. 26 de abril de 2006. p. 02.

FURTADO, Celso. Teoria Política do desenvolvimento econômico. Rio de Janeiro: Paz e Terra, 2000.

GOHN, Maria da Glória. Novas teorias dos Movimentos Sociais. São Paulo: Loyola, 2008.

HONNETH, A. Reconhecimento ou redistribuição? In.: Jessé SOUZA \& Patrícia, MATTOS. Teoria crítica no século XXI. São Paulo, Annablume, 2007. pp. 79-93.

HOBSBAWN, E. A Era das Revoluções. Rio de Janeiro: Paz e Terra, 2001.

HOONAERT, Eduardo \& DESROCHERS, Georgette (orgs.). Padre 
Ibiapina e a Igreja dos Pobres. São

Paulo: Paulinas, 1984.

IANNI, Octavio. Teorias da

Globalização. São Paulo: Civilização

Brasileira, 1997.

IZCUE, Julio Loredo. Teologia da

Libertação: um salva-vidas de chumbo

para os pobres. São Paulo: Artpress,

2016.

LOWY, Michael. O Marxismo na

América Latina: uma antologia de 1909

aos dias atuais. São Paulo: Perseu

Abramo, 2003.

LOPES, Juarez Rubens Brandão. Do

Latifúndio a empresa: unidade e diversidade do capitalismo no campo. $2^{\text {a }}$ ed. Petrópolis, RJ, Vozes, 1981.

MULLER, Gerhard Ludwig. \& GUTIÉRREZ, Gustavo. Ao lado dos pobres: Teologia da Libertação. São Paulo: Paulinas, 2017.

MOTTA, Márcia. Dicionário da Terra.

Civilização Brasileira, 2005.

MARQUES, João Jesuíno. Reforma agrária na comunidade de Fortaleza. Fortaleza, 1988.

OLIVEIRA, Ariovaldo. A agricultura camponesa no Brasil. São Paulo:

Contexto, 1997.

PACEPA, Ion. Desinformação. Vide

Editorial, 2015.

Operation Dragon. London:

Encouter books, 2021.

PAIVA, Vanilda (org). Igreja e questão

Agrária. São Paulo, Loyola, 1985.
PANINI, Carmela. Reforma Agrária dentro e fora da lei: $\mathbf{5 0 0}$ anos de história inacabada. São Paulo, Paulinas, 1990.

PIRES, Dom José Maria. Uma voz fiel a mudança social. São Paulo: Pulus, 2005. SERBIN, Kenneth P. Padres, Celibato e conflito social. Tradução: Laura Teixeira Motta. São Paulo: Cia das Letras, 2008.

SCHALL, James. Teologia da Libertação na América Latina: ensaios e documentos selecionados. Tradução: Matheus Bonetto Pacini. São Paulo: CEDET, 2020.

SIGAUD, Geraldo de Proença; MAYER, Antônio de Castro. Declaração do Morro Velho: programa de política agrária conforme os princípios de reforma agrária. $2^{\mathrm{a}}$ ed. São Paulo, Vera Cruz, 1964.

SIGAUD, Geraldo de Proença; MAYER, Antônio de Castro; OLIVEIRA, Plínio Correa de. Reforma agrária: questão de consciência. 4ed. São Paulo, Vera Cruz, 1962.

SOBRINHO, Antônio Estevam de Lima. Fome, agricultura e política no Brasil, chantagem alimentar. Petrópolis, RJ, Vozes, 1981.

SOUZA, Marcelo de Barros; CARAVIAS, José L. Teologia da Terra. Rio de Janeiro, Vozes, 1988.

TILLY, Charles. Social Movements:1768-2004. New York. Paradigm Publish, 2004. VEIGA, José Eli. O que é Reforma Agrária? 2a ed. São Paulo, Brasiliense, 1981. 
VITO, Francisco. A Encíclica "Mater et

Magistra" e a hodierna questão social.

São Paulo: Paulinas, 1987.

WALLERSTEIN, Immanuel. The

Modern World System. San Diego

Academic Press, 1989.

WOLFORD, Wendy. 'Families, fields and fighting for land: the spacial dynamics of contention in rural Brazil'. In.:

JOHNSTON, H. \& ALMEIDA, Paul.

Latin American Social Movements:

Globalization, Democratization, and

Transnational Networks. New York:

Rowman \& Littlefield Publishers, 2006.

pp. 163-176. 